\title{
Strategi Fleksibilitas Organisasi Dalam Upaya Mempertahankan Kemampuan Fisik di Masa Pandemi Covid-19 Pada Pegawai Kantor Kementerian Agama Kota Surabaya
}

\author{
Anggraini Frida Ardhani, Airlangga Bramayudha \\ Universitas Islam Negeri Sunan Ampel Surabaya \\ anggrainifrida@gmail.com
}

\begin{tabular}{l}
\hline Article Info \\
\hline Keyword: \\
Strategi fleksibilitas, \\
Ketahanan/Kemampuan \\
fisik, Covid-19, Pegawai \\
kantor pemerintah \\
\hline
\end{tabular}

Page : $61-77$

\begin{abstract}
Organizational flexibility strategy is a method that is used when the main way or the general way used by an organization to change due to other factors. This study discusses the flexibility strategy used by the Surabaya City Ministry of Religion Office in dealing with the Covid-19 pandemic. The purpose of this study is to find out how the flexibility strategy is used and whether there is a difference with the application of self-protection applied by the whole community. Researchers used qualitative research methods, descriptive approach, data collection techniques by means of interviews, documentation, and observation. Data analysis techniques started from data transcription, interview coding, topic categorization, and data analysis. The data validation technique uses participation extension and data triangulation. The results of this study explain that the employees of the ministry of religion in the city of Surabaya apply the $3 M$ health protocol as their flexibility strategy in carrying out work tasks. This government agency also implemented a Work From Home and Work From Office work system in rotation at the beginning of the COVID-19 pandemic and in the New Normal era implemented a full work system in the office.

Strategi fleksibilitas organisasi adalah sebuah cara yang digunakan pada saat cara utama yang biasa digunakan oleh sebuah organisasi menjadi berubah disebabkan faktor lain-lain. Penelitian ini membahas mengenai strategi fleksibilitas yang digunakan oleh kantor Kementerian Agama Kota Surabaya dalam menghadapi pandemi covid-19. Tujuan penelitian ini adalah mengetahui bagaimana penerapan strategi fleksibilitas yang digunakan dan apakah terdapat perbedaan dengan penerapan perlindungan diri yang diterapkan oleh seluruh masyarakat. Peneliti menggunakan metode penelitian kualitatif, pendekatan deskriptif, dan menggunakan teknik pengumpulan data dengan cara wawancara, dokumentasi, dan observasi. Teknik analisis data dimulai dari transkip data, coding wawancara, kategorisasi topik, dan analisis data. Teknik validasi data menggunakan perpanjangan keikutsertaan dan triangulasi data. Hasil penelitian ini menjelaskan bahwa para pegawai kantor Kementerian Agama Kota Surabaya menerapkan protokol kesehatan $3 \mathrm{M}$ sebagai strategi fleksibilitas mereka dalam menjalankan tugas pekerjaan. Instansi pemerintah ini juga menerapkan sistem kerja Work From Home dan Work From Office secara bergilir pada awal masa pandemi covid-19 dan pada era New Normal menerapkan sistem kerja full masuk kantor.
\end{abstract}




\section{Pendahuluan}

Strategi diperlukan untuk mengatur sebuah perusahaan atau organisasi, agar ia tetap berjalan dengan baik. Strategi dibentuk menurut jangka waktu. Strategi dapat berubah sewaktu-waktu, sesuai dengan situasi dan kondisi jaman. Seperti halnya sekarang, perusahaan atau organisasi menciptakan peraturan baru yaitu protokol kesehatan. Protokol kesehatan adalah sebuah aturan yang wajib dipatuhi oleh seluruh masyarakat pada masa pandemi covid-19 ini. Pandemi covid-19 mengharuskan perusahaan atau organisasi menciptakan peraturan baru. Rusdiya dan Rohayati mendefinisikan manajemen strategi yang berarti "rangkaian atau proses kegiatan pengambilan keputusan yang bersifat mendasar dan menyeluruh. Pengambilan keputusan itu memiliki penetapan cara pelaksanaan yang dibuat oleh manajemen puncak dan diimplementasikan oleh seluruh jajaran organisasi dalam mencapai tujuan".

Strategi berasal dari faktor dalam dan faktor luar. Strategi fleksibilitas adalah strategi yang diciptakan dari faktor luar. Fleksibilitas atau fleksibel berasal dari kata serapan bahasa inggris yang memiliki arti luwes. Strategi fleksibilitas adalah strategi yang memiliki tingkat keluwesan dalam praktik kerja. Lau, dikutip oleh Herman dalam jurnalnya, berkata "kemampuan perusahaan untuk merespon ketidakpastian dengan menyesuaikan obyektif yang ada. Respon perusahaan yang didukung oleh kemampuan dan pengetahuan superior itu disebut strategi fleksibilitas". "Hal ini

${ }^{1}$ Ujud Rusdia dan Dewi Rohayati, "Strategi Pembinaan dalam meningkatkan Kinerja Pegawai pada Dinas Cipta Karya dan Tata Ruang Kabupaten Bandung Barat", Jurnal Jisipol Ilmu Pemerintahan Universitas Bale Bandung, Vol. 4, No. 2, Juli 2020:36-52, hal 39.

${ }^{2}$ Robert Tang Herman, "Strategic Flexibility : Navigator Industri dalam mencapai Competitive menunjukkan bahwa setiap organisasi atau perusahaan wajib untuk menyusun strategi fleksibilitas. Strategi fleksibilitas bertujuan sebagai rencana yang bisa digunakan sewaktu-waktu, sesuai dengan kebutuhan organisasi. Sehingga, organisasi dapat mencapai tujuan. Parameter strategi fleksibilitas difokuskan pada kemampuan fisik pegawai.

Kemampuan kerja teramat penting bagi seluruh pegawai. Kemampuan kerja terbagi menjadi dua, yaitu kemampuan intelektual dan kemampuan fisik. Kemampuan intelektual meliputi berfikir, menalar, memecahkan masalah dan berbagai aktivitas mental lainnya. Sedangkan, kemampuan fisik meliputi kekuatan tubuh, kesehatan tubuh, stamina, keseimbangan tubuh dan kemampuan verbal pegawai. ${ }^{3}$ Kedua kemampuan tersebut sangat penting bagi kinerja dan produktivitas pegawai. Jika salah satu atau keduanya tidak terpenuhi, kinerja pegawai tidak bisa maksimal. Hal ini akan mempengaruhi pencapaian kerja organisasi.

Penelitian ini akan memfokuskan upaya pertahanan kemampuan fisik pegawai pada masa pandemi. Kemampuan fisik bisa disebut sebagai ketahanan fisik. Kemampuan fisik ialah rasa sedia dalam melakukan tugas-tugas yang menuntut stamina, keterampilan, kekuatan dan karakteristik serupa. Contoh kemampuan fisik adalah kecepatan menyelesaikan pekerjaan, disiplin bekerja, kesehatan tubuh atau bakat-bakat serupa.

Akhir tahun 2019, Kota Wuhan Cina sedang gempar munculnya virus baru yang

Advantage", Jurnal The Winners, Vol. 9, No. 1, Maret 2008:74-87, hal 76.

${ }^{3}$ Kiki Rindy Arini dkk, "Pengaruh Kemampuan Kerja dan Motivasi Kerja terhadap Kinerja Pegawai (Studi pada Pegawai PT Perkebunan Nusantara X (Pabrik Gula) Djombang Baru)", Jurnal Administrasi Bisnis, Vol. 22, No. 1, Mei 2015, hal 3. 
bernama corona virus disasea. ${ }^{4}$ Virus ini berasal dari hewan-hewan liar yang dikonsumsi masyarakat Wuhan. Virus ini menyerang sistem kekebalan tubuh dan mudah tertular kepada orang lain. Virus ini sangat mematikan. Karena itu, seseorang yang terjangkit virus ini harus dikarantina secara mandiri, baik di rumah sakit atau di rumah (isolasi mandiri). Bulan Maret 2020, corona virus disasea atau Covid-19 berhasil memasuki Negara Indonesia.

Pemerintah Indonesia mulai memberlakukan PSBB (Pembatasan Sosial Berskala Besar). PSBB adalah penutupan aktivitas kegiatan masyarakat yang berkaitan di tempat-tempat umum dan terdapat kerumuman banyak orang di tempat tersebut. PSBB memberikan dampak yang sangat besar pada segi ekonomi, segi pendidikan dan segi sosial Masyarakat Indonesia. Lembaga pendidikan mulai dari, Taman Kanakkanak hingga Universitas ditutup total. Para pelajar dan tenaga pengajar melakukan aktivitas pembelajaran di rumah masing-masing atau daring. Gedung perkantoran, pasar, mall dan fasilitas umum pun melakukan pembatasan operasi. Masyarakat yang bekerja sebagai buruh pabrik mayoritas "dirumahkan". Mereka yang bekerja secara Work From Home pun mendapatkan banyak sekali kesulitan, seperti rendahnya jaringan internet, fasilitas yang tidak memadai dan potongan gaji. Namun, PSBB tidak begitu berlaku pada Pegawai Kantor Pemerintah. Pegawai kantor pemerintah tetap datang ke kantor dan melakukan pekerjaan seperti biasanya. Hal ini dapat menimbulkan tingkat tertularnya corona virus disasea semakin besar. Sehingga, terdapat kasus banyak Pegawai Pemerintah yang terjangkit Covid-19.5 Untuk itu, organisasi perlu menciptakan strategi dalam menghadapi perubahan lingkungan yang besar. Strategi

4 International Labour Organization, Dalam menghadapi pandemi: Memastikan Keselamatan dan Kesehatan di Tempat Kerja, 2020, hal 7. ini digunakan pegawai pemerintah, agar mereka tetap dapat menjalankan pekerjaan dengan baik.

Kemampuan fisik sangat dibutuhkan bagi seluruh lapisan pekerja, tak terkecuali pegawai pemerintah. Pegawai pemerintah yang diteliti adalah pegawai Kemenag Kota Surabaya. Kankemenag Kota Surabaya adalah salah satu organisasi yang berorientasi pada keislaman. Kankemenag Kota Surabaya merupakan unit tingkatan terbawah dari Kementerian Agama Republik Indonesia. Scope organization-nya adalah Kementerian Agama Republik Indonesia (RI) - Kementerian Agama Provinsi (Kanwil) - Kementerian Agama Daerah (Kankemenag). Objek penelitian ini adalah di Kankemenag Kota Surabaya. Kemenag Kota Surabaya terletak di Jl. Masjid Agung Timur No.4 Gayungan Surabaya, Jawa Timur 60234. Kemenag Kota Surabaya dikepalai oleh Bapak Dr. Husnul Maram, M.H.I. Jumlah pegawai Kankemenag Kota Surabaya adalah 500 pegawai struktural dan 400 pegawai fungsional. Kemenag Kota Surabaya memiliki berbagai bidang. Rincian bidang yang terdapat pada Kemenag Kota Surabaya adalah bagian tata usaha umum, bagian perencana, bagian kepegawaian, bagian keuangan, bagian penyelenggara ibadah haji dan umroh, bagian pendidikan madrasah, bagian bimbingan masyarakat islam pembinaan syariah (BIMAS), bagian penerangan agama islam, bagian zakat dan wakaf, bagian pelayanan terpadu satu pintu (PTSP), serta bagian pendidikan agama

${ }^{5}$ http://m.cnnindonesia.com diakses tanggal 4 November 2020 pukul 23:22 
islam (PAIS). Bagian-bagian tersebut memiliki pegawai yang ahli dalam bidangnya. Namun, mereka memiliki kemampuan fisik yang berbeda-beda. Hal ini dikarenakan perbedaan usia, perbedan pola hidup, dan perbedaan latar belakang. Oleh sebab itu, peneliti ingin melakukan penelitian mengenai "Strategi Fleksibilitas Organisasi Dalam Upaya Mempertahankan Kemampuan Fisik di Masa Pandemi Covid-19 Pada Pegawai Kantor Kementerian Kota Surabaya”.

\section{Kajian Pustaka}

\section{Strategi}

Strategi yakni metode yang akan digunakan untuk mencapai suatu tujuan. Strategi umumnya digunakan pada saat berperang. Strategi berasal dari bahasa Yunani yaitu strategos yang berarti "komandan militer". 6 Strategi memiliki pengertian secara etimologi (asal kata). Dalam menajemen, strategi berarti cara, kiat, dan taktik yang sistematik untuk melaksanakan fungsi manajemen. Strategi diciptakan terarah pada tujuan strategi organisasi. ${ }^{7}$ B. B. Tregoe dan John W. Z. melansir buku Top Management Strategy, mendefinisikan strategi sebagai "kerangka kerja yang memandu pilihan yang menentukan sifat dan arah organisasi". ${ }^{8}$ Handoko, dikutip oleh Rusniati dan Haq, mengatakan "strategi memberikan arahan terintegrasi untuk organisasi.

${ }^{6}$ www.wikipedia.com diakses tanggal 5 November 2020 pukul 13:22

${ }^{7}$ Ujud Rusdia \& Dewi Rohayati, Strategi Pembinaan Dalam Meningkatkan Kinerja Pegawai, hal 39.

${ }^{8}$ Academia.edu, pengertian visi, nilai dasar dan strategi misi.

${ }^{9}$ Rusniati dan Ahsanul Haq, "Perencanaan Strategis dalam Perspektif Organisasi", Jurnal Intekna,
Strategi juga menetapkan pedoman untuk memelihara sumber daya organisasi yang digunakan untuk mencapai tujuan". ${ }^{9}$

Strategi memiliki berbagai macam bentuk. Mulai dari, strategi ekonomi, strategi organisasi, strategi manajemen, strategi sumber daya manusia, strategi bisnis, strategi militer, strategi keuangan, strategi pendidikan dan lainlain sebagainya. Strategi yang akan digunakan dalam penelitian kali ini adalah strategi organisasi. Strategi organisasi memiliki beberapa macam. Strategi organisasi yang peneliti pakai adalah strategi fleksbilitas organisasi.

Fred R. David, dikutip oleh Rusdiya dan Rohayati, mengatakan "studi tentang membuat, menerapkan, dan mengevalausi keputusan lintas fungsi yang memungkinkan organisasi untuk mencapai tujuan adalah definisi manajemen strategi. Strategi adalah serangkaian tindakan dan alokasi sumber daya juga diterapkan sangat penting untuk mencapai rancangan organisasi. Strategi tersebut menetapkan tujuan dasar jangka panjang dan tujuan organisasi.". ${ }^{10}$ Dessler, dilansir dari peran strategis manajemen sumber daya manusia, mengatakan "vital human asset the executives is the connecting of human asset the board with key job and destinations to improve business execution and create hierarchical societies and quicker development and adaptability". ${ }^{11}$

Tahun XIV, No. 2, Nopember 2014 : 102 - 209, hal 105.

${ }^{10}$ Ujud Rusdiya dan Dewi Rohayati, "Strategi Pembinaan Dalam Meningkatkan Kinerja Pegawai", hal 40.

${ }^{11}$ Nenah Sunarsih, "Manajemen Sumber Daya Manusia Berbasis Kompetensi: Strategi Meningkatkan Kemampuan Daya Saing 
Manajer memiliki strategi dalam meningkatkan kinerja dengan mengaitkan sumber daya manusia. Hal ini dapat membangun budaya organisasi dengan memanfaatkan inovasi dan fleksibilitas. Henry Mintzberg, dikutip pada buku Manajemen Strategi oleh Taufiqurrokhman, menulis tentang "strategi memiliki lebih dari dua elemen definisi, yaitu sebagai perencanaan (plan) dan pola (pattern). Tapi, ia mengatakan bahwa definisi strategi telah berkembang menjadi tiga 'P' baru, yaitu posisi (position), perspektif (perspective), dan penerapan (poly)". ${ }^{12}$

\section{Strategi Fleksibilitas Organisasi} Seperti namanya, strategi fleksibilitas merupakan strategi yang sifatnya lentur. Lentur yang dimaksud adalah dia dapat berubah sewaktuwaktu mengikuti perubahan yang ada. Perubahan yang terjadi dapat berasal dari internal atau dalam maupun dari eksternal atau luar. Perubahan internal dapat meliputi: re-strukturisasi organisasi, kuantitas dan kualitas sumber daya manusia, proses produksi, standar operasional prosedur (SOP), kebijakan pimpinan dan lain sebagainya. Sedangkan, perubahan eksternal dapat meliputi: kebijakan pemerintah, tingkat permintaan dan penawaran masyarakat, perubahan lingkungan, politik, sosial budaya, dan lainnya. Penelitian ini akan berfokus pada perubahan eksternal yaitu perubahan lingkungan. Perubahan lingkungan yang terjadi dikarenakan munculnya pandemic atau penyakit

Perusahaan", Jurnal Akrab Juara, Vol. 3 No. 1, Februari 2018: 17-28, hal 21.

${ }^{12}$ Taufiqurokhman, Manajemen Strategik, (Jakarta: Fakultas IImu Sosial dan IImu Politik Universitas Prof. Dr. Moestopo Beragama), hal 37. yang sedang menyerang seluruh dunia (global). Karena itu, tiap-tiap perusahaan atau organisasi telah merumuskan strategi baru, yang mampu beradaptasi dengan perubahan lingkungan yang ada.

Wibowo, dikutip oleh Hiariey, menyatakan "fleksibilitas berkaitan dengan siklus suatu organisasi dalam merespon perubahan lingkungan". ${ }^{13}$ Dikutip pada jurnal yang sama, Grant menyatakan strategi sebagai "suatu pertimbangan akan kemampuan yang dinamis dan dinyatakan pada satu hierarki yaitu fleksibilitas. Kemampuan tersebut berupa: operasional, struktural dan strategis".. ${ }^{14}$ Tietze dan kawan-kawan, melansir pada jurnal International Critical Management Studies Conference, menekankan "strategi as a structural flexibility allows for quick adaption to enviromental changes ". ${ }^{15}$ Fleksibilitas yakni kapasitas untuk bertahan hidup/bekerja secara efektif dan efisien. Fleksibilitas dapat dilakukan pada seorang atau kelompok. Ketika, seseorang menciptakan fleksibilitas maka wajib memiliki sudut pandang yang berbeda dan kontradiktif terhadap suatu permasalahan. Pendekatan fleksibilitas dalam organisasi adalah dapat menerima perubahan dengan mudah sesuai keadaan. Lau, dikutip oleh Herman dalam jurnalnya, berkata "kemampuan perusahaan untuk merespon ketidakpastian dengan menyesuaikan obyektif yang ada. Respon perusahaan yang didukung oleh kemampuan dan pengetahuan superior itu disebut

\footnotetext{
${ }^{13}$ Harvey Hiariey, "Pengaruh Kualitas Sumber Daya Manusia dan Fleksibilitas Organisasi Terhadap Kinerja Pegawai, hal 111.

${ }^{14}$ Ibid, hal 112.

${ }^{15} 4$ th International Critical Management Studies Conference
} 
strategi fleksibilitas". ${ }^{16} \mathrm{Yu}$, dikutip oleh Kumalaningrum dalam jurnalnya, berkata "salah satu bentuk kapabilitas organisasi yang dapat mengidentifikasi perubahan adalah fleksibilitas organisasi. Identifikasi dilakukan secara cepat dan tepat dengan mengalokasikan sumber daya pada proyek baru. Proyek tersebut harus dapat merespon perubahan, dan dapat bertindak mengubah komitmen alokasi sumber daya yang sudah ada" ${ }^{17}$

Shagvaliyeva dan Yazdanifard, dalam jurnal milik Capnarry, mengatakan "contoh dari fleksibilitas kerja adalah jam kerja yang fleksibel. Hal tersebut dapat dilihat dari anggota organisasi yang dapat memanajemen atau mengontrol waktu kerja berdasarkan area atau lokasi kerja dan memiliki kapasitas yang dapat memenuhi jadwal atau program kerja yang diberikan". ${ }^{18}$ Pegawai diuntungkan dengan adanya fleksibilitas kerja. Adanya fleksibilitas kerja dapat menarik, mendapatkan, dan mempertahankan pegawai dengan kualitas yang bagus.

Waktu atau jam kerja yang fleksibel memiliki efek yang baik pada kesehatan mental pegawai dan dapat menyusutkan tingkat stress. Kinicki dan Kreitner, dikutip oleh Capnarry dalam jurnalnya, berkata bahwa "pengaruh positif pada kepuasan kerjaa diperoleh dari kesehatan mental

\footnotetext{
${ }^{16}$ Robert Tang Herman, "Strategic Flexibility : Navigator Industri Dalam Mencapai Competitive Advantage", hal 76.

${ }^{17}$ Maria Pampa Kumalaningrum, “Kapabilitas Kewirausahaan dan Profitabilitas: Peran Moderasi Fleksibilitas Strategi”, JRAK, Vol. 8, No. 2 Agustus 2012, hal 127.

${ }^{18}$ Muhammad Calvin Capnary dkk, "The Influence of Flexibility of Work to Loyalty and Employee Satisfication Mediated by Work Life Balance to Employees", Jurnal Business: Theory and Practice, Okotber 2018:217-227, hal 218.
}

pegawai". ${ }^{19}$ Shimizu dan Hitt, dikutip oleh Choir dalam skripsinya, mengatakan "fleksibilitas strategi yakni kapabilitas suatu organisasi nirlaba dan laba dalam menemukan faktor perubahan utama dari faktor lingkungan luar atau eksternal, menempatakan pegawai baru untuk mengenal dan merespon perubahan yang terjadi, dan untuk bertindak segera misalnya komitmen". ${ }^{20}$

Novela, dalam e-papernya di investor.id, menerangkan bahwa tujuan fleksibilitas organisasi ada dua, yaitu sebagai berikut: Menciptakan kreasi dan pengembangan diri pada pegawai secara kreatif dan aktif. Serta, memperoleh pegawai atau talent yang baik untuk strategis mempertahankan pegawai yang berkualitas. ${ }^{21}$

Shimizu dan Hitt, dikutip oleh Choir dalam skripsinya, menerangkan pengambilan keputusan untuk mempertahankan fleksibilitas strategi menggunakan tiga kemampuan dan bertahap yakni:

1) Memperhatikan umpan balik negative dan mempertahankan kemampuan berpikir.

2) Mengumpulkan dan mengevaluasi data negative secara obyektif.

3) Memulai dan membuat perubahan keseluruhan dalam kerangka waktu yang baik

\footnotetext{
${ }^{19}$ Ibid, hal 218.

${ }^{20}$ Hanggana Raras Prima Choir, "Pengaruh Fleksibilitas Strategi Terhadap Kinerja Perusahaan (Studi Pada KUD Tani Wilis Kecamatan Sendang Kabupaten Tulungagung)", Skripsi, Universitas Bhayangkara Malang, 2020, hal 2.

${ }^{21}$ Intan Novela, "Pengaturan Kerja Fleksibel Era New Normal", investor.id, diakses tanggal 16 November 2020 pukul 1:25
} 
bahkan dalam menghadapi ketidakpastian. $^{22}$

Albion, dikutip oleh Capnarry, mengemukakan fleksibilitas kerja memiliki empat kategori. Kategori tersebut terbagi menurut jam kerja yang menyusut tanpa mengurangi gaji atau upah. Berikut kategori fleksbilitas organisasi:

1) Pengaturan sistem kerja yang mengedepankan fleksibilitas. Pegawai dapat mengerjakan pekerjaannya dari luar kantor, bahkan dari rumah. Sistem kerja ini sekarang disebut sebagai Work Form Home (WFH).

2) Pengaturan dalam bentuk pengurangan jam dan upah.

3) Pengaturan hak yang dibayar dan cuti terkait keluarga.

4) Ketentuan ad hoc untuk keadaan yang tidak diketahui. Ad hoc adalah kekhususan untuk sesuatu hal yang masih belum pasti. ${ }^{23}$

Adapun bentuk strategi fleksibilitas organisasi dapat berupa: tempat kerja yang fleksibel, pegawai yang fleksibel, pimpinan yang fleksibel, jadwal yang fleksibel. ${ }^{24}$

\section{Kemampuan Fisik Pegawai}

Sumber daya manusia ialah aset penting dalam organisasi. Jika manusia yang akan mengerjakan pekerjaan organisasi tidak ada, maka tujuan organisasi tidak akan tercapai. Pekerjaan yang tidak selesai akan menimbulkan masalah yaitu organisasi tidak akan mencapai tujuan yang sebenarnya. Sebagai pemegang peran nomor satu pada sebuah organisasi, sumber daya manusia atau bisa disebut sebagai pegawai harus dapat mengerjakan kewajiban yang dimiliki dengan sangat baik. Pegawai perlu memiliki pengetahuan, keterampilan dan kekuatan dalam menyelesaikan pekerjaan. Ketiga hal itu disebut sebagai kemampuan kerja.

Robbins, dikutip oleh Endayani, membagi kemampuan kerja menjadi dua, yaitu kemampuan intelektual dan kemampuan fisik. $^{25}$ Kedua kemampuan tersebut sangat erat hubungannya dengan perubahan lingkungan yang terjadi. Terlebih, kemampuan fisik memiliki peran yang sangat kuat terhadap perubahan lingkungan yang sedang mencekam. Gondokusumo, dikutip oleh Sarworini, mengatakan "kemampuan fisik mengacu pada kondisi fisik, kesehatan, tingkat keliatan, dan fungsi biologis suatu bagian tubuh tertentu" 26

Robbins, dikutip oleh Mahmudi, mengatakan bahwa "kekuatan, stamina, keterampilan, dan kecekatan yang dipakai untuk mengerjakan tugas disebut kemampuan fisik.". ${ }^{27}$ Robbins dan

\footnotetext{
${ }^{22}$ Hanggana Raras Prima Choir, "Pengaruh Fleksibilitas Strategi Terhadap Kinerja Perusahaan", hal 4.

${ }^{23}$ Muhammad Calvin Capnary dkk, "The Influence of Flexibility of Work to Loyalty and Employee Satisfication Mediated by Work Life Balance to Employees", hal 219.

${ }^{24}$ The Balance Careers, "Workplace Flexibility Definition With Examples", diakses tanggal 16 November 2020 pukul 1:21
} 
Judge, dikutip oleh Risqon, mengatakan "kemampuan fisik yakni kapasitas pegawai pada kondisi tertentu untuk mencapai keberhasilan pekerjaan yang tidak memakai keterampilan dan standar". ${ }^{28}$ Suwarto, dikutip oleh Humaeriah, berkata "faktor yang mempengaruhi kinerja seseorang yakni kemampuan fisik, kemampuan psikis, dan, faktor lingkungan". 29

Robbins, dikutip oleh Suryani, menyebutkan bahwa kemampuan fisik memiliki berbagai macam bentuk, adapun di antaranya adalah kekuatan dinamis, kekuatan tubuh, kekuatan verbal, koordinasi tubuh, keseimbangan tubuh, dan stamina tubuh. ${ }^{30}$

Kemampuan fisik dapat dianalogikan dengan kemampuan berkreativitas. Kemampuan fisik dapat berupa pekerjaan yang membutuhkan daya tahan, ketangkasann fisik, kecekatan tangan, kekuatan kaki, atau keterampilan serupa yang mengharuskan manajer untuk mengidentifikasi kemampuan fisik karyawan. $^{31}$

Adapun kegiatan-kegiatan yang perlu diperhatikan dalam mempertahankan kemampuan fisik adalah sebagai berikut: kesehatan tubuh, kesehatan mental, pola makan yang baik, olahraga yang teratur, pengendalian stres yang baik, pola hidup yang sehat dan istirahat yang cukup.

\section{Pandemi}

Pandemi adalah sebuah momok yang ditakuti oleh seluruh masyarakat dunia. Pandemi sendiri adalah sebuah penyakit yang menjangkiti seluruh sebagian besar negara di dunia. Skala yang terjadi pada pandemi adalah skala global. Hal tersebut berarti pandemi memiliki tingkat penularan yang sangat tinggi karena mampu menyerang hingga mayoritas penduduk bumi. Pandemi yang sedang menakuti seluruh penduduk dunia adalah corona virus disasea atau Covid-19. Hal ini bukan pertama kalinya pandemi menyerang negara-negara dibelahan bumi. Pada tahun 20022003 munculah pandemi Severe Acute Respiratory Syndrome (SARS) yang merupakan famili dari coronavirus. ${ }^{32}$

WHO (World Health Organization) mendefinisikan "pandemic is a flare-up of a sickness that happens over a wide
Perilaku Waktu Kerja terhadap Kinerja Pegawai Di PT. Airmancur Solo", hal 3.

${ }^{28}$ Muhammad Risqon dan Didik Purwadi, "Pengaruh Kepemimpinan, Kompensasi dan Kemampuan Kerja terhadap Kinerja Pegawai", Jurnal Ekonomi Manajemen Sumber Daya, Vol. 13, No. 1, Juni 2012, hal 37.

${ }^{29}$ Hani Humaeriah, "Pengaruh Kemampuan Intetektual dan Kemampuan Fisik Pegawai terhadap Kinerja Pegawai di Kantor Pusat Disnakertrans Provinsijawa Barat", Jurnal llmu Manajemen \& Bisnis, Vol. 6 No. 1, Maret 2015, hal 12.
${ }^{30}$ Dedy Suryani, "Pengaruh Kemampuan Pengetahuan,Keterampilan,Sikap Kerja Pegawai Pada Koperasi Simpan Pinjam Karya Utama", Skripsi, Universitas Islam Negeri Maulana Malik Ibrahim Malang, hal

${ }^{31}$ Susi Susilawati Harahap, "Hubungan Usia, Tingkat Pendidikan, Kemampuan Bekerja dan Masa Bekerja terhadap Kinerja Pegawai dengan menggunakan Metode Pearson Correlation", Jurnal Teknovasi, Vol. 6, No. 2 2019:12-26, hal 22.

${ }^{32}$ Wening Widjajanti, "Penyakit yang pernah Mewabah di Dunia", www.b2p2vrp.litbang.kemkes.go.id diakses tanggal 16 Januari 2021 pukul 11:18 
geographic zone, (for example, numerous nations or landmasses) and normally influences a huge extent of the populace: a pandemic flare-up of an illness". ${ }^{33}$ Parameter pandemi yang akan dibahas pada penelitian kali ini adalah pandemi Covid-19. Covid 19 atau biasa disebut virus corona merupakan virus baru yang dikenal sindrom pernapasan atau paru-paru yang akut SARS-CoV-2. Kasus ini di awali negara Cina yang terletak dikota Wuhan pada bulan akhir tahun $2019 .{ }^{34}$

WHO atau World Healtth Organization mengemukakan pula pandemi sebagai penyebaran penyakit ke seluruh dunia. Istilah pandemi sebagian besar merujuk pada penyakit yang meluas secara geografis. Wabah pandemi pernah terjadi pada abad ke -14 seperti kolera, influenza, dan virus human immunodeficiency (HIV/AIDS).

Corona Virus atau Severe

Acute Respiratoryy Syndrome Coronavirus 2 (SARS-CoV-2) adalah virus tersebut menyerang paru-paru atau sistem pernapasan. Awal gejala virus tersebut yakni gangguan ringan pada sistem pernapasan, lalu infeksi pada paruparu jika infeksi tersebut stadium berat maka menimbulkan kematian. ${ }^{35}$ Yuliana menjelaskan dalam jurnalnya bahwa gejalagejala yang bisa timbul akibat terjangkit Covid-19 adalah sebagai berikut: demam, batuk kering, bersin, sesak napas, sakit tenggorokan, nyeri kepala,

33 Merriam Webster, "Pandemic Dictionary", diakses tanggal 26 Oktober 2020 pukul 23:19

34 International Labour Organization, Dalam menghadapi pandemi: Memastikan Keselamatan dan Kesehatan di Tempat Kerja, 2020, hal 7. mialgia/artralgia, menggigil, muntah/mual, kongesti nasal, diare, nyeri abdomen, hemoptisis, kongesti konjungtiva. ${ }^{36}$

Awal mula penyebaran virus corona adalah dari hewan kepada manusia. Akan tetapi, penularan bisa terjadi antara manusia dengan manusia. Seperti yang dikutip peneliti dari website kesehatan terpercaya di Indonesia, yaitu alodokter.com, cara penularan antar sesama manusia dapat berupa:

1) Terkena percikan ludah atau droplet yang keluar dari seorang yang terpapar covid-19 saat bicara,batuk, dan bersin.

2) Mulut atau hidung yang terpegang sebelum mencuci tangan dengan sabun setelah menyentuh barang yang terkena percikan atau cipratan dari ludah atau seorang yang terpapar covid-19

3) Kontak langsung dengan orang yang positif covid$19 .{ }^{37}$

Pencegahan adalah suatu hal yang lebih bijaksana dilakukan pada saat kondisi terlampau genting seperti ini. Bahkan, ada peribahasa mengatakan "mencegah lebih baik daripada mengobati". Dengan melalukan pencegahan, kita dapat melindungi diri dan orang lain dari tertularnya penyakit yang mematikan ini. Walaupun, vaksin corona virus

\footnotetext{
${ }^{35}$ www.alodokter.com/virus-corona diakses tanggal 1 Januari 2021, pukul 00:22

${ }^{36}$ Yuliana, "Coronavirus Disasea 2019: Tinjauan Literatur Terkini", Wellness and Healthy Magazine, Vol. 2 No. 1, Februari 2020: 187-192, hal 189-190. ${ }^{37}$ www.alodokter.com/virus-corona
} 
sedang dalam tahap pembuatan dan akan dilanjut uji coba. Masyarakat dapat melakukan pencegahan dengan cara:

1) Jaga jarak atau biasa disebut physical distancing minimal 1 meter dari orang lain.

2) Ketika beraktivitas di keramaian atau tempat umum harus menggunakan masker.

3) Cuci tangan merupakan hal wajib dilakukan. Cuci tangan dengan air mengalir dan sabun. Jika tidak ada air bisa memakai hand sanitizer yang mengandung alkohol minimal $60 \%$.

4) Ketika akan menyentuh mata, mulut, atau hidung lakukan cuci tangan terlebih dahulu.

5) Pola hidup sehat bisa membuat imun kuat. Cara membuat imun kuat dengan konsumsi makanan yang bergizi dan matang, olahraga rutin, istirahat cukup, berjemur di bawah matahari, dan cegah stress.

6) Ketika bersin atau batuk biasakan menutup mulut dan hidung dengan tisu, jika tidak punya bisa menggunakan siku tangan.

7) Dilarang kontak langsung pada orang yang positif covid-19 atau orang yang memiliki gejala virus tersebut.

8) Jaga kebersihan lingkungan sekitar. ${ }^{38}$

Pemerintah merangkum tindak pencegahan di atas menjadi 3M, yaitu Menjaga jarak, Memakai masker dan Mencuci tangan.

Pemerintah mewajibkan masyarakat mematuhi protokol kesehatan tersebut tanpa terkecuali. Protokol kesehatan ini bahkan sudah diterapkan oleh seluruh warga dunia.

\section{Metode Penelitian}

Peneliti menggunakan metode penelitian kualitatif dengan pendekatan deskriptif. Sumber data yang digali pada penelitian ini berasal dari data utama (primer) dan data penunjang (sekunder). Sumber data pada penelitian ini merupakan narasumber, yaitu pegawai Kantor Kementerian Agama Kota Surabaya. Peneliti mengumpulkan data dengan teknik wawancara, observasi dan dokumentasi. Peneliti mewawancarai 5 narasumber, yang mana di antaranya adalah: pegawai bagian kepegawaian, pegawai haji dan umroh, pegawai bimbingan masyarakat, dan pegawai umum. Adapula teknik yang digunakan peneliti untuk memvalidasi data adalah transkrip, coding, kategorisasi.

\section{Hasil dan Pembahasan}

Berdasarkan sub bab penyajian data, penulis akan merumuskan hasil analisis data. Seluruh temuan dalam penyajian data akan dirumuskan dengan menyambung pada teori-teori yang telah

\footnotetext{
${ }^{38}$ www.alodokter.com/virus-corona
} 
didapatkan. Dalam sub bab analisis data ini, penulis akan menjabarkan teori yang didapat dengan hasil temuan di lapangan.

Setiap perusahaan atau organisasi wajib memiliki pedoman dalam mengerjakan tugasnya. Bagian-bagian yang terdapat pada perusahaan atau organisasi memiliki tugas yang berbedabeda. Mereka memiliki tupoksinya sendirisendiri. Akan tetapi, tujuan mereka tetap satu yaitu mencapai tujuan organisasi. Kankemenag Kota Surabaya memiliki tujuan memberikan pelayanan yang baik dan maksimal kepada masyarakat dan calon jamaah haji. Pedoman yang digunakan itu adalah peraturan dari pusat. Sehingga, Kankemenag Kota Surabaya mengacu pada peraturan dari Kankemenag Republik Indonesia. Adanya sistem kerja yang terstrukturisasi, Kementerian Agama Kota Surabaya berada di bawah naungan Kantor Wilayah Kementerian Agama Provinsi Jawa Timur. Berdasarkan letak geografis, Kankemenag Kota Surabaya harus mengikuti Peraturan Daerah, khususnya Peraturan Daerah Kota Surabaya.

Pedoman merupakan bagian dari strategi. Strategi adalah kiat atau cara yang digunakan untuk mencapai sebuah tujuan. Strategi biasanya bersifat paten atau mutlak. Namun, adapula strategi yang bersifat dinamis. Strategi yang dinamis disesuaikan dengan faktor eksternal yang datang. Strategi Kankemenag Kota Surabaya dalam menghadapi Covid-19 antara lain, menerapkan protokol kesehatan 3M yang berlaku pada masyarakat. Setiap tamu yang masuk wajib memakai masker, mencuci tangan terlebih dahulu, dan di cek suhu badannya. Pada saat di PTSP tamu wajib menjaga jarak dalam duduk dan berbicara kepada resepsionis. Pihak Kankemenag juga memberikan mika plastik sebagai pembatas antara tamu dan resepsionis. Tak hanya itu, Kankemenag juga menyediakan pelayanan secara online jadi tamu dapat mengontrol permintaannya melalui website Kankemenag Kota Surabaya.

$$
\text { Strategi yang digunakan }
$$

Kankemenag Kota Surabaya merupakan edaran yang diberikan oleh Kementerian Pusat. Selain itu, Kankemenag juga melakukan surat perintah dari Wali Kota. Namun, Kankemenag Kota Surabaya tetap bertanggung jawab pada Kementerian Agama Pusat atau Presiden. Surat edaran dari Perwalian Surabaya menyatakan bahwa Kankemenag berlokasi di daerah Surabaya. Surat edaran tersebut dirumuskan oleh presiden dan jajarannya.

Kankemenag Kota Surabaya menerapkan strategi yang dirumuskan oleh atasan mereka, Kementerian Agama Pusat. Penerapan strategi mereka adalah mematuhi protokol kesehatan 3M dan selalu menjaga daya tahan tubuh dengan kesadaran diri masing-masing. Pandemi Covid-19 ini selalu menjadi berita utama, pegawai Kankemenag Kota Surabaya telah memiliki kesadaran mereka masingmasing. Pegawai yang memiliki kesadaran, akan lebih baik menjaga kemampuan fisik yang mereka punya. Pegawai yang memiliki kesadaran akan bahaya Covid-19 tidak akan menyepelekan kondisi pandemi saat ini.

Kankemenag Kota Surabaya memberikan respon yang positif terhadap pandemi Covid-19 ini. Jika, mereka memberikan respon negatif artinya mereka mengabaikan semua protokol kesehatan $3 \mathrm{M}$ yang berlaku dan bertindak semaunya. Kankemenag Kota Surabaya tidak bakal memberikan respon negatif, karena mereka berada dalam pengawasan pemerintah. Kankemenag Kota Surabaya adalah organisasi pemerintgah yang mana artinya mereka dibawah pengawasan pemerintah dan wajib mengikuti apa yang telah ditetapkan oleh presiden. Respon positif yang diberikan Kankemenag Kota Surabaya adalah menciptakan gugus Covid-19 internal, seperti sekuriti yang 
sigap dalam memeriksa setiap tamu yang datang.

Pada Kankemenag Kota Surabaya terdapat peraturan bahwa setiap ASN wajib masuk selama 5 hari kerja. Saat masa pandemi, peraturan tersebut berubah menjadi masuk kantor selama 2-3 hari atau Work From Office dan sisa hari kerjadibuat kerja dari rumah atau biasa disebut Work From Home. Work Form Home atau bekerja dari rumah adalah sistem kerja baru yang tercipta pada saat pandemi Covid-19 datang ke Indonesia. Sistem kerja ini tercetus karena perusahaan besar atau organisasi pemerintah harus tetap melakukan pekerjaan tapi tidak perlu datang ke kantor atau bertatap muka dengan orang lain. Work From Home dapat dilakukan dengan aplikasi zoom, whatsapp, google meet, dan teleconference lainnya. Selain itu, Work Form Home dapat dilakukan di manapun, baik pegawai tersebut berada di rumah, di dapur, dan dimanapun pegawai berada.. Work From Home merupakan salah satu alternatif agar pegawai tetap bisa bekerja, kantor dapat melakukan pekerjaan tanpa harus PHK. Work From Home ini dilakukan pada saat daerah lokasi kantor berzona merah. Jika, daerah tersebut ternilai sudah aman atau zona hijau maka ASN masuk kantor secara full.

Pegawai Kankemenag Kota Surabaya memiliki rasa tanggung jawab yang besar. Hal ini dapat dibuktikan dengan responsif mereka dalam menghadapi pandemi. Pegawai melaksanakan WFH/WFO dengan baik sesuai jadwal yang tertera. Pegawai tetap menggunakan masker walau sedang di dalam ruangan. Pegawai tetap menjaga jarak dengan tamu yang datang dan rekan kerja yang lain. Pegawai menghilangkan salaman tangan yang biasa dan membiasakan tos siku. Pegawai tetap melaksanakan tugasnya dibuktikan dengan laporan harian yang selalu diselesaikan.
Kondisi kesehatan para pegawai Kankemenag Kota Surabaya terlihat segar bugar Alhamdulillah. Walau memang pada awal-awal pandemi ada yang terjangkit covid-19 sebanyak 2-3 pegawai namun sekarang mereka dinyatakan telah sembuh dan dapat bekerja kembali. Kondisi psikis para pegawai terlihat stabil. Mereka tetap bekerja seperti biasanya. Kinerja kerja para pegawai tetap stabil sebelum masa pandemi. Laporan harian yang wajib disetorkan kepada kasi berjalan dengan lancar tanpa hambatan. Berkaitan dengan kinerja, tugas dinas luar kota yang biasa dilakukan oleh para pegawai pun berangsur diselenggarakan pada saat New Normal ini. Syarat mengikuti dinas luar adalah rapid/swab. Para pegawai Kankemenag Kota Surabaya melakukan rapid/swab sebelum melakukan dinas luar kota. Pada saat menghadiri dinas luar kota tetap menjaga diri sesuai dengan protokol kesehatan yang berlaku.

Setiap organisasi pemerintah haruslah memiliki fasilitas yang memadai bagi pegawainya. Di masa pandemi ini wajarlah jika diadakan fasilitas yang menunjang. Hanya saja, Kankemenag Kota Surabaya tidak memiliki klinik kesehatan yang seperti itu, pegawai Kankemenag juga tidak mendapatkan rapid/swab tes secara massal. Jika pegawai merasa kondisi tubuhnya sedang tidak baik pada saat di kantor, pegawai tersebut disarankan untuk pulang atau pegawai tersebut dapat periksa di puskesmas terdekat. Untungnya, Kankemenag Kota Surabaya berada di jarak yang terjangkau pada puskesmas terdekat. Jika ada pegawai yang mengalami gejala Covid-19 harus langsung melakukan tes rapid/swab dengan biaya mandiri. Untungnya, seluruh pegawai memiliki BPJS.

Walaupun, Kankemenag Kota Surabaya tidak memberikan klinik kesehatan dan tes rapid/swab massal secara gratis. Seluruh pegawai Kankemenag Kota Surabaya mendapatkan alat penunjang 
pencegahan penularan Covid-19. Adapun alat penunjang tersebut seperti, pembagian masker, pembagian sarung tangan, pembagian vitamin, pembagian hand sanitizer, dan penyemprotan desinfektan secara berkala pada setiap sebelum atau sesudah kegiatan. Pegawai juga mendapatkan keringanan seperti, jika merasa sakit dapat izin pulang dan mendapatkan gilir bekerja dari rumah, yang mana pegawai dapat memberikan lebih banyak waktu untuk keluarga.

Sistem kerja WFH atau WFO yang diterapkan oleh pegawai Kankemenag Kota Surabaya berjalan seperti yang telah peneliti sampaikan sebelumnya. Pada saat WFH, pegawai hanya perlu masuk ke kantor sebanyak 2-3 hari, dan di dalam ruangan hanya boleh 2-3 orang, bergantung pada jumlah total pegawai di tiap ruangan. Dengan sisa hari tersebut, pegawai digilir untuk masuk kantor dan bekerja dari rumah. Dalam hal ini, ada beberapa pegawai yang merasa tidak efektif melakukan WFH karena fokus konsenstrasinya dapat terpecah antara mengerjakan tugas kantor dan mengerjakan pekerjaan seorang istri/suami. Namun, kebanyakan dari mereka, sangat menyukai WFH. Karena, bisa lebih banyak meluangkan waktu untuk anak-anaknya/keluarga. Pada intinya, WFH/WFO yang dilaksanakan Pegawai Kankemenag tetap berjalan dengan lancar dan efektif.

Seperti yang telah peneliti jelaskan di atas, Kankemenag Kota Surabaya pun menerapkan protokol kesehatan yang berlaku secara umum di masyarakat, yaitu protokol kesehatan 3M (memakai masker, mencuci tangan, menjaga jarak). Protokol kesehatan ini berlaku bagi seluruh pegawai dan tamu pengunjung yang masuk tanpa terkecuali. Sistem kerja pegawai dan sistem pelayanan pada masyarakat juga menerapkan protokol kesehatan ini dengan baik. Bapak kepala juga selalu memberikan arahan dan mengingatkan untuk selalu mematuhi protokol kesehatan di mana pun kapan pun, baik melalui acara formal ataupun sekedar lewat whatsapp grup. Tak hanya itu, tunjangan seperti pemberian masker gratis, sarung tangan, vitamin, hand sanitizer, dan desinfektan pun diberikan satu paket pada setiap pegawai. Untuk hand sanitizer dan desinfektan diberikan pada setiap bagian ruangan bukan per-individu. Jadi, tidak ada alasan pegawai tidak menjalankan protokol kesehatan yang sudah ditetapkan.

Dalam kesehariannya, para pegawai Kankemenag Kota Surabaya membudidayakan 3M, mencuci tangan, menggunakan masker, menjaga jarak. Sama seperti perlakuan kepada tamu, para pegawai pun harus menerapkan protokol kesehatan kepada sesama rekan kerja. Perbedaan yang datang pada masa pandemi awal adalah tidak adanya absensi checklock, sehingga jika para pegawai hendak absen mereka menggunakan aplikasi kemenag yang dimiliki di handphone masing-masing pegawai. Perbedaan kedua adalah ditiadakannya apel pagi dan senam bersama setiap hari jumat. Hal itu bertujuan untuk mengurangi penggerombolan dan pencegahan menggunakan physhical distancing, karena lahan yang dimiliki oleh Kankemenag Kota Surabaya pun sangat terbatas. Namun, waktu senam bersama di hari jumat tetap tidak hilang, dan digunakan bagi para pegawai yang ingin berolahraga dengan tetap melakukan olahraga, seperti caring, volly, atau jogging keliling Masjid Al-Akbar.

Kesehatan para pegawai yang tetap stabil dan bahkan meningkat menjadi lebih baik disebabkan oleh kepatuhan mereka dalam menerapkan protokol kesehatan yang berlaku dan kesadaran masingmasing akan menjaga kesehatan tubuh. Para pegawai Kankemenag kota surabaya melakukan olahraga rutin setiap harinya di rumah, makan makanan yang bergizi, mengimbangi dengan vitamin dan 
suplemen supaya imun tetap terjaga dan tetap melakukan pekerjaan sebagai kewajibannya agar badan senantiasa tetap bergerak. Hal ini menciptakan kondisi jasmani yang sehat dan kondisi psikis yang baik sehingga virus yang hendak menjangkiti tubuh menjadi lemah dan mati.

\section{Kesimpulan}

Hasil studi lapangan dan analisis pembahasan tentang strategi fleksibilitas organisasi pada Kankemenag Kota Surabaya, peneliti dapat menyimpulkan bahwa para pegawai Kankemenag Kota Surabaya menerapkan protokol kesehatan yang berlaku pada masyarakat semenjak adanya pandemi Covid-19 yang menyerang seluruh negara di dunia. Protokol kesehatan yang berlaku tersebut merupakan $3 \mathrm{M}$ yaitu mencuci tangan, memakai masker dan menjaga jarak minimal 1 meter. Protokol kesehatan ini dibuat oleh pemerintah dan dianjurkan untuk dipatuhi oleh seluruh lapisan masyarakat indonesia, tak terkecuali para pegawai Kankemenag Kota Surabaya. Protokol kesehatan 3M yang diterapkan pada Kankemenag Kota Surabaya wajib ditaati oleh seluruh pegawai dan tamu yang berkunjung. Absensi pegawai tidak lagi dilakukan pada fingerprint checklock tapi menggunakan fingerprint pada aplikasi Kankemenag khusus pegawai pada $\mathrm{hp}$ masing-masing. Kegiatan senam pada hari jumat pun ditiadakan untuk menghindari kerumunan. Senam hari jumat diganti olahraga volly, badminton, dan caring (berjemur) masing-masing bagi yang menginginkan. Pada pelayanan, Kankemenag menyediakan tempat cuci tangan dengan sabun bagi tamu, pengecekan suhu tubuh oleh satpam yang berada di depan pintu depan. Untuk PTSP (Pelayanan Terpadu Satu Pintu), Kankemenag Kota Surabaya memberikan pembatas mika plastik yang terdapat antara resepsionis dan tamu. Tamu juga dapat melakukan permintaan pelayanan melalui online di website Kemenag Kota Surabaya. Sehingga, tamu tidak perlu keluar rumah dan bertemu dengan orang lain untuk memeriksa proses layanannya.

Secara garis besar, tidak ada yang berbeda dari protokol kesehatan yang berlaku di masyarakat dengan protokol kesehatan yang digunakan pada Kankemenag Kota Surabaya. Karena, Kankemenag Kota Surabaya adalah organisasi pemerintah yang berada di bawah naungan pemerintah. Sehingga, seluruh pegawai Kankemenag harus melakukan perintah yang dibuatkan oleh pemerintah kepada seluruh lapisan masyarakat tanpa terkecuali.

\section{Daftar Pustaka}

Agusta, I. (2003). Teknik Pengumpulan dan Analisis Data Kualitati. Penelitian Metode Kualitatif di Pusat Penelitian Sosial Ekonomi (hal. 1-11). Bogor: Litbang Pertanian.

Andi Eldi Indra Malika, d. (2020). Pengaruh Disiplin Kerja, Motivasi Kerja, dan Kemampuan Fisik terhadap Kinerja Pegawai. Journal Center of Economic Student, 73-89. Anggitasari, H. H. (2015). Pengaruh Kemampuan Intelektual dan Kemampuan Fisik Pegawai terhadap Kinerja Karyawan di Kantor Pusat Disnakertrans 
Provinsi Jawa Barat. Jurnal Ilmu Manajemen \& Bisnis, Vol. 6, No. 1, 11-20.

Bachri, B. S. (2010). Meyakinkan Validitas Data melalui Triangulasi pada Penelitian Kualitatif. Jurnal Teknologi Pendidikan, 46-62.

C, H. R. (2020). Pengaruh Fleksibilitas Strategi terhadap Kinerja Perusahaan (Studi Pada KUD Tani Wilis Kecamatan Sendang Kabupaten Tulungagung), Skripsi. Malang: Universitas Bhayangkara.

Doyle, A. (2020, July 06). The Balance. Dipetik November 16, 2020, dari The Balance Careers: https://www.thebalancecareers.co $\mathrm{m}$ /workplace-flexibility-definitionwith-examples

Fidati, R. (t.thn.). Wordpress. Dipetik November 6, 2020, dari wordpress.com:

rindufidati.wordpress.com/haditshadits-tentang-kesehatan

Harahap, S. S. (2019). Hubungan Usia, Tingkat Pendidikan, Kemampuan Bekerja dan Masa Bekerja terhadap Kinerja Pegawai dengan menggunakan Metode Pearson Correlation. Jurnal Teknovasi, 1226.

Hasanah, H. (2016). Teknik-teknik Observasi. Jurnal at-Taqaddum, 22-46.

Herman, R. T. (2008). Strategic Flexibility: Navigator Industri dalam Mencapai Competitive Advantage. Jurnal The Winners, Vol. 9, No. 1, 74-87.

Hiariey, H. (2018). Pengaruh Kualitas Sumber Daya Manusia dan Fleksibilitas Organisasi terhadap Kinerja Karyawan (Studi Terhadap Paramedis Keperawatan RSUD Dr. M. Haulussy Ambon). Jurnal SOSOQ, 108-121.

Jannah, R. K. (2019). Penerapan Customer Relationship Management (CRM) dan Kualitas Pelayanan Sebagai
Upaya Mempertahankan Loyalitas Jamaah Umrah di Intanaya Tour and Travel. Surabaya: Universitas Islam Negeri Sunan Ampel Surabaya.

Kiki Rindy Arini, d. (2015). Pengaruh Kemampuan Kerja dan Motivasi Kerja terhadap Kinerja Karyawan (Studi pada Karyawan PT Perkebunan Nusantara X Pabrik Gula Djombang Baru). Jurnal Administrasi Bisnis, Vol. 22, No. 1, 1-9.

Kumalaningrum, M. P. (2012). Kapabilitas Kewirausahaan dan Profitabilitas: Peran Moderasi Fleksibilitas Strategi. JRAK, 125-137.

Mahmudi, A. (2013). Analisis Kemampuan Intelektual, Kemampuan Fisik, Sikap Terhadap Pekerjaan, dan Perilaku Waktu Kerja terhadap Kinerja Karyawan di PT. Airmancur Solo, Skripsi. Solo: Universitas Muhammadiyah Surakarta.

Muhammad Calvin Capnary, d. (2020). The Influence of Flexibility of Workto Loyalty and Employee Satisfication Mediated by Work Life Balance to Employees with Millenial Generation Background in Indonesia Startup Companies. Jurnal Business: Theory and Practice, 217-227.

Mulyadi, M. (2011). Penelitian Kuantitatif dan Kualitatif serta Pemikiran Dasar Menggabungkannya. Jurnal Studi Komunikasi dan Media, Vol. 15, No. 1, 127-138.

Novela, I. (2020, July 12). Investor.id. Dipetik November 16, 2020, dari https://investor.id/opinion/pengatu ran-kerja-fleksibel-era-new-normal

Nugrahani, F. (2014). Metode Penelitian Kualitatif: dalam penelitian pendidikan bahasa. Solo: Cakra Books. 
Nuraini, D. (2017). Pengaruh Fleksibilitas Kerja dan Spesialisasi Pekerjaan terhadap Kinerja Karyawan dengan Kepuasan Kerja Sebagai Variabel Mediating Pada PT. Daya Manunggal Salatiga, Tesis. Solo: Universitas Muhammadiyah Surakarta.

Organization, I. L. (2020). Dalam Menghadapi Pandemi: Memastikan Keselamatan dan Kesehatan di Tempat Kerja. Switzerland: Labour Administration, Labour Inspection.

Pandiangan, H. (2018). Flexible Working Arrangement dan Pengaruhnya terhadap Work Life Balance pada Driver Layanan Jasa Transportasi Online di Kota Yogyakarta, Tesis. Yogyakarta: Universitas Sanata Dharma.

Pane, M. D. (2020, Desember 21). alodokter. Dipetik January 1, 2021, dari alodokter.com: https://www.alodokter.com/viruscorona

Raco, J. R. (2010). Metode Penelitian Kualitatif: Jenis, Karakteristik dan Keunggulannya. Jakarta: PT Gramedia Widiasarana Indonesia.

RI, H. K. (2021, January 5). Kementerian Agama. Dipetik January 3, 2021, dari Kemenag.go.id: https://kemenag.go.id/home/artikel /42956/sejarah

Rika, H. (2020, September 7). CNN Indonesia. Dipetik November 4, 2020, dari cnnindonesia.com: https://m.cnnindonesia.com/nasion al/75-persen-pns-di-zona-merahcorona-dilarang-berkantor

Rohayati, U. R. (2020). Ujud Rusdia dan Dewi Rohayati, "Strategi Pembinaan Dalam Meningkatkan Kinerja Pegawai Pada Dinas Cipta Karya Dan Tata Ruang Kabupaten Bandung Barat", Jurnal. Jisipol
Ilmu Pemerintahan Universitas Bale Bandung Vol. 4, No. 2, 36-52. Sarworini, F. (2007). Hubungan Kemampuan Dan Motivasi Terhadap Kinerja Pegawai Dinas Kependudukan, Tenaga Kerja dan Transmigrasi Kab Karanganyar, Skripsi. Solo: Universitas Muhammadiyah Surakarta.

Sianturi, B. (2019, Juni 4). Wikipedia. Dipetik November 5, 2020, dari Wikipedia:

https://id.m.wikipedia.org/wiki/str ategi

Subadi, T. (2006). Metode Penelitian Kualitatif. Surakarta: Muhammadiyah University Press.

Sudarsono, B. (2003). Dokumentasi Informasi dan Demokratisasi. BACA, Vol. 27 No. 1, 7-14.

Sunarsih, N. (2018). Manajemen Sumber Daya Manusia Berbasis Kompetensi: Strategi Meningkatkan Kemampuan Daya Saing Perusahaan. Jurnal Akrab Juara, Vol. 3, No. 1, 17-28.

Suryani, D. (t.thn.). Pengaruh Kemampuan (Pengetahuan, Keterampilan, Sikap) Kerja Karyawan pada Koperasi Simpan Pinjam Karya Utama, Skrips.

Syauqi, M. I. (2020, Maret 24). Islami Corporated. Dipetik November 6, 2020, dari islami.co: https://islami.co/thaun-atau-peswabah-penyakit-menular-di-masarasulullah

Taufiqurokhman. (2016). Manajemen Stratejik. Malang: Fakultas Ilmu Politik.

Webster, M. (2020, Desember 27). Merriam Webster Incorporated. Dipetik Oktober 26, 2020, dari merriam-webster.com: http://www.merriamwebster.com/dictionary/pandemic

Wicaksono, I. S. (2019). Pengaruh Kompensasi dan Fleksibilitas 
Kerja Driver Gojek terhadap Kinerja dengan Kepuasan Kerja Sebagai Variabel Intervening, Skripsi. Yogyakarta: Universitas Islam Indonesia.

Yuliana. (2020). Coronavirus Disasea 2019: Tinjauan Literatur Terkini. Wellness and Healthy Magazine, Vol. 2, No. 1, 187-192.

Zakariya, N. A. (2019). Koordinasi Kinerja Penjaga Kantor (Studi pada Pelayanan Santri dan Wali Santri serta Manajemen Keuangan di Kantor Pondok Pesantren Roudlotul Qur'an Tlogoanyar Kab. Lamongan, Skripsi. Surabaya: Universitas Islam Negeri Sunan Ampel. 